\title{
Assessment of the Partial Purified Lipid a Extracted from Proteus mirabiliscell Wall as Adjuvant Immunotherapy
}

\author{
Rawenq Zuhir ${ }^{1}$, Mouruj A. Alaubydi ${ }^{2}$ \\ Dept. of Dentistry, Dijlah University College \\ Dept. of Biotech, University of Baghdad, Collage of Science
}

\begin{abstract}
P.mirabilis is considered one of the nosocomial infection causative agent, and its importance is related with the wide separation in different ecosystem, in addition to its relationship with renal and bile calculi, and because of an increase of bacterial resistance, this study goal to find substitutional substance used to treat bacterial infection through using natural biomaterial, thus using LPS (Lipid A moiety) as adjuvant immunotherapy by different routes of administration(Oral, intraperitoneal, and subcutaneous) and find the best one. The results showed, recovered lipid A was obtained from both collected LPS of pathogenic P.mirabilis isolate and standard bacteria approximately represented $20 \%$ of LPS amount, with LD50 $0.6 \mathrm{Mg} / \mathrm{ml}$ for the pathogenic one. The estimation of some immune parameters such as IL-1ß showed i.p administration was led to a significant elevation of this interleukin in compared with other routes and control groups. Meanwhile, IL-2, IL-10, and IFN- $\gamma$ percentages showed a significant elevation in all treated groups in compared with control. While TNF- $\alpha$ percentage revealed variation in levels according to the route of administration, simultaneously both intraperitoneal and subcutaneous routes showed a significant elevation. Whereas the IgG level exhibited, no significant alteration observed with any treated groups in compared with control one.
\end{abstract}

Keywords: Proteus mirabilis lipid A , Lipid A, Lipopolysaccharide, Immunotherapy, Adjuvant

\section{Introduction}

Lipid A is the hydrophobic anchor of lipopolysaccharide, which forms the outer monolayer of the outer membranes of most gram-negative bacteria. It is embedded in a matrix of phospholipid and protein $(1,2)$.It is the most conservative part of LPS, which is responsible for its toxicity and it has a specific effect on monocytes and macrophages. In macrophage, lipid A triggers the synthesis of diverse inflammatory mediators, such as TNF- $\alpha$ and IL1- $\beta$, as well as enhance the production of co-stimulatory molecules, which is needed for the adaptive immune response, While in mononuclear and endothelial cells, lipid A enhances tissue factor production (3). On the other hand, adjuvants are compound which increases the immunogenicity of the antigens and act to up-regulate immune responses to improve vaccine efficacy and efficiency (4). They differ in their mode of action, some of them are capable to transfer long-term presentation of the antigen, which is known as depot effect, whereas others assist to target immune cells as in delivering the antigen to APCs or by showing a capacity to enhance the production of different cytokine patterns by activating different pattern-recognition-receptors (PRRs), and shifting the immune response towards Th-1 or Th-2, another possibility, the adjuvant may enhance the levels of co-stimulatory molecules on APCs (5). The experiment of chemically modified LPS concluded that only the lipid A part is needed for adjuvanticity. The most desirable characteristics of modern adjuvant vaccines are the safety, reactogenicity, and the ability to increase a specific efficacy of the vaccine $(6,7)$. The removal of endotoxins from materials designed for use on humans, as well as the animals considered as an important field of study in applied biotechnological science (3). Thus this study was aimed to assess using of lipid A extracted from Proteus mirabilis LPS as adjuvant immunotherapy with the suitable route of administration .

\section{Materials and Methods}

Depending on previous study (8) LPS was extracted from both pathogenic Proteus mirabilis isolate and standard Proteus mirabilis bacteria/ ATTC. 7002, REF.0607S, United States of America.

Lipid A extraction: According to Deleo and Otto,( 9), lipid A was extracted from LPS by solubilized in $0.02 \%$ triethylamine and acetic acid $/ \mathrm{BDH}$, the mixture was added at a final concentration of $15 \%$, heated at $100^{\circ} \mathrm{C}$ for 2 hours and then cooled. Lipid A was quantitatively precipitated by adding $1 \mathrm{M} \mathrm{HCl}(\mathrm{BDH})$ at a final $\mathrm{pH}$ 1.5. Insoluble lipid $\mathrm{A}$ was centrifuged at $2000 \times \mathrm{g}$ and washed three times with cold D.W.

\section{Determination of lipid A LD50}

According to Bandekar, and Nerkar,( 10), a total of 30 albino mice were divided into three groups for the detection of lipid A LD50, they were intraperitoneally injected with three different concentration $(0.8,0.6$ and 0.4$) \mathrm{Mg} / \mathrm{ml}$.

\section{In vivo tests}

In this experiment 51 albino mice were used, each tested group included 5 mice whereas each control group included 3 mice only. Depending on the result of the LD50 experiment, the amount and conc. of the dose was determined, and the mice divided into 13 groups according to the route of administration, as bellows:

Group 1: Negative control

Volume 6 Issue 12, December 2017 


\section{International Journal of Science and Research (IJSR) \\ ISSN (Online): 2319-7064}

Index Copernicus Value (2016): 79.57 | Impact Factor (2015): 6.391

Groups 2,3, and 4: Represented as Control groups administered complete and incomplete Freund's adjuvant $(0.6 \mathrm{Mg} / \mathrm{ml})$, (Orally, intraperitoneal, and subcutaneously) respectively.

Group 5,6, and 7: Act as Control groups administered aluminum hydroxide $(0.6 \mathrm{Mg} / \mathrm{ml})$ (orally,intra peritoneal, and subcutaneously) respectively.

Group 8, 9, and 10: Represented as tested groups administered $0.6 \mathrm{Mg}$ of partially purified lipid A for pathogenic isolate (intraperitoneal, subcutaneously, and orally) respectively

Group 11,12,and13: Act as a comparative experiment administered $0.6 \mathrm{Mg}$ of partially purified lipid A of standard strain ( intraperitoneal, subcutaneously, and orally) respectively .

\section{Immunization schedule}

Mice in each group were injected daily for seven days and monitored for 14 days from the first dose. The blood sample was pooled from the heart using a $3 \mathrm{ml}$ syringe and transferred into gel tube, centrifuged and the serum was stored at $-20{ }^{\circ} \mathrm{C}$ for further immunological parameter studies.

Preparation of killed Staphylococcus aureus vaccine (11) In order to prepare the Staphylococcus aureus killed vaccine. S.aureus was activated by inoculated into tryptic soy broth/himedia (India), incubated for 24 hours at $37{ }^{\circ} \mathrm{C}$. Killed vaccine was prepared by heating the culture at $100{ }^{\circ} \mathrm{C}$ for $30 \mathrm{~min}$. Finally, the vaccine sterility was tested by streaking loop full of heat treated bacterial suspension on nutrient agar/ himedia (India), and incubated overnight at $37 \circ \mathrm{C}$.

The bacterial suspension was centrifuged and the bacterial pellet was washed 3 times with distilled water, the sediment was collected and used as a killed bacterial antigen for the vaccine, and the concentration of bacterial growth was counted by comparing with the McFarland standard solution $\left(1 \times 10^{8}\right)$.

\section{Challenge test}

The numbers of 15 mice were divided into 3 groups, each one included 5 mice. They were immunized (orally, subcutaneously and intraperitoneal ) with $30 \mathrm{Ml}$ of prepared vaccine mixture $(25 \mathrm{Ml}$ killed vaccine $+5 \mathrm{Ml}$ lipid $\mathrm{A}$ $(0.6 \mathrm{Mg} / \mathrm{ml}))$, then a booster dose was given after a week from the first one and monitored another week. All groups of animals, (control and treated) were deeply scratched in the dorsal site, and infected with live activated Staphylococcus aureus broth $(1 \times 10 \quad 8 \quad \mathrm{CFU} / \mathrm{ml})$, and monitored for the period of infection and healing .

Quantitative determination of IgG antibodies: The procedures were done as instructed by Cloud-Clone Corp company.

Quantitative determination of interleukins: Both of IL-1 and IL-2 Immunoassay were done as instructed by Abcam Company. IL-10 Immunoassay was done as instructed by Cloud-Clone Corp Company. Whereas both of INF-gamma and TNF-alpha Immunoassay were applied as instructed by Alpha diagnostic international Company.

\section{Result and Discussion}

\section{Lipid A separation}

Lipid A was split up by mild acid hydrolysis from the lipopolysaccharide of Proteus mirabilis. Amount of recovered lipid A was obtained from both collected LPS of pathogenic P.mirabilis isolate and standard bacteria (28.5 and 18.5) $\mathrm{mg}$ from (150 and $95 \mathrm{mg}) \mathrm{mg}$ of LPS. Respectively, approximately represented $20 \%$ of LPS amount. The recovered Lipid A in present study disagreed with that reported by Lukasiewicz and coworkers (12) found the recovered amount was $11-16 \%$ of LPS. This differentiation may be due to, structural analysis of lipid A within individual organisms resulting from different growth conditions (e.g. temperature), as well as among various organisms yields a remarkable amount of variation (13).Lipid A diversity has been attributed to the action of "latent" enzyme that modifies the biochemically conserved lipid A molecule(14), these variations in lipid A structure may contribute to bacterial virulence by mitigating early innate immune defense responses to infection (15). Heat and mild acid hydrolysis method was considered a sufficient to disrupt the heat labile linkage between lipid A backbone and the ketodeoxyoctanoate (KDO) in the LPS core, as well the insolubility of lipid A in water made it easier to separate by centrifugation (9).

\section{In vivo test: Lethal Dose 50 (LD50) of lipid A}

LD50 of lipid A was identified; it was $0.6 \mathrm{Mg} / \mathrm{ml}$, this result was confirmed to that obtained by (10).

\section{Quantitative determination of interleukins $1 \beta, 2,10$, TNF alpha, IFN- $\gamma$ by ELISA}

The serum levels of five cytokines (IL-1 $\beta$, IL-2, IL-10, TNF- $\alpha$, IFN- $\gamma$ ) were assessed in treated groups and compared with the control groups.

\section{Interleukin $1 \beta$}

This interleukin is one of $\mathrm{IL}-1$ member, possess a strong pro-inflammatory effect, produced by various cell types including peripheral blood monocytes, macrophages, Bcells, Th lymphocytes and NK cells (16). The results of IL$1 \beta$ in this study revealed, a significant decrease $(\mathrm{P} \leq 0.05)$ or no effect in most treated groups except that treated intraperitoneal (i.p) with lipid A of isolated bacteria, these results reflect extracted lipid A was acting perfectly as an adjuvant with the vaccine administered i.p. Since this interleukin is pro-inflammatory material, therefore its good in stimulation both immune responses with low toxicity, which was proved by Okemoto et al., (17) they mentioned, lipid A failed to induce activation of caspase-1, which catalyzes IL-1beta precursor processing. These results suggest that an immune response without activation of caspase-1 led to lowering toxicity of this adjuvant, also ILlbeta promotes cell growth, tissue repair, and immune response regulation and have a significant role in many chronic and acute inflammatory diseases $(18,19)$. On the other hand, the decline in its concentration for other routes

\section{Volume 6 Issue 12, December 2017}




\section{International Journal of Science and Research (IJSR) \\ ISSN (Online): 2319-7064}

Index Copernicus Value (2016): 79.57 | Impact Factor (2015): 6.391

of treatments made this material may act as antiinflammatory agent, when administered orally or subcutaneous (table 1)

\section{Interleukin 2 (IL- 2)}

This interleukin produced primarily by activated type 1 CD4+ T cells (Th1 cells), and stimulates proliferation of activated $\mathrm{CD} 4+, \mathrm{CD} 8+$, promotes the differentiation of cytotoxic $\mathrm{T}$ lymphocytes and functions as a $\mathrm{T}$ cell chemoattractant factor $(20,21)$. The results in a table (1), showed a significant elevation $(\mathrm{P} \leq 0.05)$ in all treated groups in compared with control groups. The intraperitoneal groups of both standard and pathogenic bacteria represented the best one, that made it a good immune stimulant. The present study showed lipid A can be used as a carrier with hapten antigens in preparation of vaccine to direct the immune response towered the haptin. When the results of this study compared with that obtained about another adjuvant, lipid A appeared more effective than other, these results agreed with Carozziet al., (22), reported, the in vitro incubation of Peritoneal Lymphocytes(Ply) and Peritoneal macrophages with escalating doses of MPLA enhances of GammaInterferon and IL-2 production by PLy, as well as agreed with that mentioned by De Becker et al.,( 23) about the ability of MPL to enhances macrophages and B cells to sensitize naive $\mathrm{T}$ cells. Administration of MPL i.p. in mice result in the redistribution of fully mature dendritic cells (DC) in the $\mathrm{T}$ cell area of the spleen. These observations suggested that MPL may induce an antigen-specific primary immune response by provoking the migration and maturation of DC that are the physiological adjuvant of the immune system. On the other hand, DC IL-2 has been shown to be important for innate and adaptive immune responses. Depending on the elevation in level IL-2 levels in the present study, we can suggest that there were similarities between extracted lipid A and that for MPL in activating innate immune cells response.

\section{Interleukin (IL)-10 and interferon (IFN)- $\gamma$}

Interleukin-10 was identified as a "cytokine synthesis inhibitory factor" which is a product of $\mathrm{Th}_{2}$ cells following protein or antigenic stimulation that, block cytokine production from $\mathrm{Th}_{1}$ cells. IL-10 achieved this effect by inhibiting the ability of macrophages and dendritic cells to activate $\mathrm{Th}_{1}$ cells (24), however, IL-10 can also be produced by most if not all CD4+ $\mathrm{T}$ cell subsets, including $\mathrm{Th}_{1}$ and $\mathrm{Th}_{17}$ cells, B cells, neutrophils, and macrophages. The investigations demonstrated that $\mathrm{T}$ - regular cells serve as major source of IL-10, and by which regulate the immune response (25). In this regard, it has been found that IL-10 inhibits the protective immune response to pathogens by blocking the production of pro-inflammatory cytokines, such as TNF- $\alpha$. It's also capable to inhibit phagocytosis and microbial killing through limiting the production of reactive oxygen and nitrogen intermediates in response to INF- $\gamma(26$, 27). IL-10 enhances B cells survival, proliferation, and differentiation and modulates class-switch recombination and induces the $\mathrm{IgG}$ production. Furthermore, the overexpression induces anti-inflammatory cytokines in B cells (28). The recent result of this study showed the level of IL-10 revealed a significance elevation $(\mathrm{P} \leq 0.05)$ in all treated groups, in addition to the positive comparable adjuvant of control groups. These results reflected the compatibility of lipid A to act as adjuvant like other types of usable one. In addition confirmed that previously mentioned about IL-1 $\beta$, table (1).The results were agreed with that reported by Salkowski and cohorts (29) they suggested that enhanced production of IL-10 by MPL-stimulated macrophages may contribute to reducing the toxicity of MPL through its negative action on induction of cytokines. These findings assist in understanding the cellular mechanisms by which MPL induces host cell activation and subsequent adjuvant properties. Therefore according to the results, lipid A may be safe to use as an adjuvant, as well as lipid A action on IL-10, looks like that of MPL.

Interferon- $\gamma$ is synthesized mostly by $\mathrm{Th}_{1}$ lymphocytes, after their activation with immune and inflammatory stimuli, rather than viral infection (30). Interestingly, natural killer cells can furthermore function as "adaptive effectors" once activated by $\mathrm{T}$ cell-induced IFN- $\gamma$ or when IgG eventually elicits antibody-dependent cell cytotoxicity $(31,32)$. IFN- $\gamma$ secreted to activate macrophages and to induce their microbicidal functions (33). Although it's is essential for the development of an immune response, that prolongs the lifespan of an infected animal (34).IFN- $\gamma /$ IL-10 ratio reflecting the $\mathrm{Th}_{1} / \mathrm{Th}_{2}$ balance in serum (35).

The present results of this cytokine showed a significance increasing $(\mathrm{P} \leq 0.05)$ in the levels of all treated and positive adjuvants control groups in comparison with the negative control, as well these results reflected the compatibility among adjuvants groups and lipid A table (1), and agreed with Werner-Felmayer and coworkers (36) reported lipid A is a bacterial compound tested strongly increased the effects mediated by IFN- $\gamma$. On the other hand, the elevation of this cytokine is very important in the stimulation of both immune responses (innate and adaptive), throughout the macrophages which acts as antigen presenting cells then stimulate $\mathrm{Th}_{1}$. Hence both cells are active in the production of IFN- $\gamma$. These results in the recent study confirmed with that recorded about IL-2, through possibility use lipid A as a carrier for the haptin antigen.

TNF- $\alpha$ is a cytokine associated with acute and chronic inflammation. It is produced chiefly by activated macrophages, although it can be produced by many other cell types such as CD4+ lymphocytes, NK cells, neutrophils, mast cells, and eosinophil's (37).

The results of this cytokine showed variation in its levels according to the route of administration. Both intraperitoneal and subcutaneous routes showed a significant elevation $(\mathrm{P} \leq 0.05)$ in TNF- $\alpha$ level of both lipid A extracts (standard and isolated bacteria), while orally rout showed a significance decreases $(\mathrm{P} \leq 0.05)$ in the level of this cytokine table (1), Therefore it can be considered as a suitable adjuvant, when used orally. lipid A provides another important point about the possibility to be used as antitumor if administered I.P and S/C, throughout elevation of TNF- $\alpha$ level in addition to other cytokines. These results were agreed with that reported by Martin et al .,(38) documented that MPL differentially utilizes TLR2 and TLR4 for the induction of TNF- $\alpha$, IL-10, and IL-12 through purified human monocytes as well as by human peripheral blood mononuclear cells in vitro.Since the effects of lipid A (in

\section{Volume 6 Issue 12, December 2017}




\section{International Journal of Science and Research (IJSR) \\ ISSN (Online): 2319-7064}

Index Copernicus Value (2016): 79.57 | Impact Factor (2015): 6.391

vivo) when injected i.p or s/c similar to that effects in vitro, because these routes of administrations are concerned systemic routes, made the macrophages and other mononuclear cells that found in blood or in essential organ such as liver, and spleen to exposed directly to lipid A .

\section{Effect of lipid A on antibody level ( IgG)}

The effects of Lipid A on the antibody production in mice were proven. No significant alteration of the $\operatorname{IgG}$ antibody level was observed in any treated groups in compared with control one. However, both lipid A of( standard and isolated) bacteria have the capacity to increase the antibody titer, after secondary injection with the antigen for intraperitoneal groups $(\mathrm{P} \leq 0.05)$ only, table (2). An activation of immunological memory in the absence of primary antibody response is suggested. This result agreed with that reported by Thalhammer and his partner (39) about elevation of IgG titer after a second exposure to the Lipid A.

These results supported that demonstrated by Kolb et al., (40) in adult mice. The reasons may be due to many factors affecting on the production of IgG serum level, that related with the properties of an antibody such as titer, duration of response, isotype and subclass, avidity, specificity for available determinants, properties of cell-mediated immunity. Other characteristics like development of memory, effectiveness of mucosal immunization, incidence of genetic non-responders (41).

In addition, the route and dose amount significantly influenced serum antibody responses and protection, as well as the mouse age (42). Thus we can conclude, the elevation of INF- $\gamma$ and IL-10 led to counteract significant elevation of IgG level. Lipid A may acts as a good adjuvant and carrier, through directed the immune system toward binding antigen and stimulation $\mathrm{Th}_{1}$ cytokines such as IL-2 and IFN- $\gamma$ are expressed more strongly than the $\mathrm{Th}_{2}$ cytokines (43). IFN- $\gamma$ and IL-2 induced the cellular immunity, while IL-10 inhibits TNF- $\alpha$ and IL-1 $\beta$ level in serum, thus inhibit the inflammation as Szczepanik et al., (44) documented.

\section{Challenge test}

Challenging the mice with prepared killed vaccine and lipid A(as adjuvant) for one week followed with a booster dose, they were monitored after scratching the dorsal region of the animal and infected with virulent S.aureus. The results showed the control group was infected with severe inflammation, abscess and subjected to death within five days, the death began at the second day after infection, while the immunized groups with prepared vaccine showed minor symptoms of inflammation and started to heal from the fifth day and the healing completed after a week from the booster dose. These results agreed with that reported by Roquillyet al., (45) who mentioned, when infection was induced by methicillin-susceptible S.aureus, and Monophosphoryl lipid A, which was administered intravenously, they showed that this compound decreased systemic dissemination of $S$. aureus and inhibited the inflammatory lung lesions. Ex-vivo MPLA stimulated either dendritic cells or natural killer cells. Dendritic and natural killer cells are involved in the beneficial effects of MPLA within post-hemorrhage pneumonia. We can suggest that lipid A stimulated both dendritic and natural killer cells, therefore lipid A may be effective as an adjuvant with $S$. aureus by dimension its bacterial effect.

Table 1.1: Interleukins level in the treated groups

\begin{tabular}{|c|c|c|c|c|c|c|}
\hline \multirow[t]{2}{*}{ Group } & \multicolumn{6}{|c|}{$\begin{array}{c}\text { Cytokines level in } \mathrm{pg} / \mathrm{ml} \text { Mean } \pm \mathrm{SE} \\
(\mathrm{P} \leq 0.05)\end{array}$} \\
\hline & IL-1 $\beta$ & IL-2 & IL-10 & TNF- $\alpha$ & INF- $\gamma$ & $\mathrm{IgG}$ \\
\hline Control & $30 \pm 1.11$ & $12.5 \pm 0.13$ & $16.7 \pm 2.12$ & $250 \pm 0.87$ & $200 \pm 0.54$ & $4.1 \pm 1.10$ \\
\hline $\begin{array}{l}\text { CFA+IFA } \\
\text { Orally }\end{array}$ & $15 \pm 1.13$ & $22 \pm 0.32$ & $28 \pm 1.32$ & $220 \pm 0.74$ & $250 \pm 0.13$ & $3.5 \pm 0.12$ \\
\hline $\begin{array}{l}\text { CFA+IFA } \\
\text { I.P }\end{array}$ & $16 \pm 0.71$ & $20 \pm 1.54$ & $26 \pm 0.65$ & $215 \pm 0.32$ & $233 \pm 0.11$ & $4 \pm 0.34$ \\
\hline $\begin{array}{l}\text { CFA+IFA } \\
\text { S/C }\end{array}$ & $14 \pm 1.4$ & $20 \pm 1.54$ & $25 \pm 1.6$ & $210 \pm 0.5$ & $221 \pm 0.1$ & $3.8 \pm 0.1$ \\
\hline $\begin{array}{l}\text { Aluminum hydroxide } \\
\text { Orally }\end{array}$ & $21 \pm 1.12$ & $42 \pm 0.13$ & $45 \pm 0.45$ & $233 \pm 0.16$ & $300 \pm 0.54$ & $4 \pm 0.12$ \\
\hline $\begin{array}{l}\text { Aluminum hydroxide } \\
\text { I.P }\end{array}$ & $33 \pm 0.21$ & $32 \pm 0.32$ & $36 \pm 0.13$ & $256 \pm 0.76$ & $310 \pm 0.11$ & $4.5 \pm 0.32$ \\
\hline $\begin{array}{l}\text { Aluminum hydroxide } \\
\text { S/C }\end{array}$ & $26 \pm 0.81$ & $29 \pm 0.12$ & $32 \pm 0.1$ & $240 \pm 0.61$ & $303 \pm 0.55$ & $4.1 \pm 0.13$ \\
\hline $\begin{array}{l}\text { Standard P.mirabilis } \\
\text { orally }\end{array}$ & $18 \pm 0.14$ & $21 \pm 0.8$ & $27 \pm 0.42$ & $223 \pm 1.65$ & $219 \pm 0.12$ & $3.9 \pm 0.65$ \\
\hline $\begin{array}{c}\text { Standard P.mirabilis } \\
\text { I.P }\end{array}$ & $31 \pm 0.43$ & $39 \pm 0.11$ & $52 \pm 0.12$ & $300 \pm 0.32$ & $320 \pm 0.32$ & $4.6 \pm 1.11$ \\
\hline $\begin{array}{l}\text { Standard P.mirabilis } \\
\text { S/C }\end{array}$ & $27 \pm 0.51$ & $31 \pm 0.53$ & $39 \pm 0.65$ & $276 \pm 0.54$ & $245 \pm 0.11$ & $4.3 \pm 0.11$ \\
\hline $\begin{array}{c}\text { pathogenic P.mirabilis } \\
\text { Orally }\end{array}$ & $12 \pm 0.12$ & $28 \pm 0.65$ & $28 \pm 0.11$ & $221 \pm 0.15$ & $250 \pm 0.63$ & $3.7 \pm 0.42$ \\
\hline $\begin{array}{c}\text { pathogenic P.mirabilis } \\
\text { I.P }\end{array}$ & $45 \pm 1.21$ & $46 \pm 1.11$ & $46 \pm 0.89$ & $340 \pm 0.18$ & $288 \pm 1.12$ & $4.8 \pm 0.71$ \\
\hline $\begin{array}{c}\text { pathogenic P.mirabilis } \\
\text { S/C }\end{array}$ & $21 \pm 1.34$ & $34 \pm 0.18$ & $43 \pm 0.56$ & $299 \pm 0.31$ & $254 \pm 0.32$ & $4.1 \pm 0.11$ \\
\hline
\end{tabular}




\section{International Journal of Science and Research (IJSR) \\ ISSN (Online): 2319-7064}

Index Copernicus Value (2016): 79.57 | Impact Factor (2015): 6.391

\section{Conclusions}

We can concluded that, there was compatibility in immune effect between extracted lipid A and documented MPLA, throughout induces potent responses with low toxicity. On the other hand there were similarities in the effect between lipidA and other traded known adjuvants, meanwhile lipid A showed diversities in effect according to the routes of administration. Since some of routes recorded elevation in the TNF- $\alpha$, therefore lipid A act as a promising biological agent against cancer. Lastly the bioavailability effect of lipidA with prepared killed $S$. aureus, made this agent as a good, economic, and safe adjuvant.

\section{References}

[1] Ramsey, R.B.; Hamner, M.B.; Alving, B.M.; Finlayson, J.S.; Alving, C.R.; and Evatt, B.L.(1980). Effects of lipid A and liposomes containing lipid A on platelet and fibrinogen production in rabbits. Blood. 56(2):307-10.

[2] Raetz, C. R.; and Whitfield, C. (2002). Lipopolysaccharide endotoxins. Annual review of biochemistry., 71: 635-700.

[3] Boratyński, J. A. N. U. S. Z.; Syper, D. A. N. U. T. A.; Weber-Dabrowska, B.; Łusiak-Szelachowska, M. A. R. Z. A. N. N. A.; Poźniak, G. R. Y. Z. E. L. D. A.; and Górski, A. N. D. R. Z. E. J. (2004). Preparation of endotoxin-free bacteriophages. Cell MolBiolLett., 9(2); 253-9.

[4] Jawyn, N. (2011). MECHANISMS OF ADJUVANT INDUCTION OF THE INNATE IMMUNE (Doctoral dissertation, The University of Akron).

[5] Althaus, K. (2009). Mechanism of the adjuvant activity of the synthetic mycobacterial cord factor analog Trehalose-6, 6-dibehenate (TDB). München, Techn. Univ., Diss., 2010.

[6] Morrison, D. C.; and Ryan, J. L. (1992). Bacterial endotoxic lipopolysaccharides (Vol. 2). CRC Press.

[7] Pasquale, A. D.; Preiss, S.; Silva, F. T. D.; and Garçon, N. (2015). Vaccine Adjuvants: from 1920 to 2015 and Beyond. Vaccines., 3(2): 320-343.

[8] Zuhair.R and Alaubaydy.M.A. Immunological assesment of Lipid A extracted from urinary tract Proteus mirabilis samples.(2015).(MSC thesis .University of Baghdad).

[9] DeLeo, F. R; and Otto, M. (2008). Bacterial pathogenesis: methods and protocols. Springer Science \& Business Media. (Vol. 431):10.

[10] Bandekar, J. R., \&Nerkar, D. P. (1988). Biological activities of lipid A from Vibrio parahaemolyticus: stimulation of murine peritoneal macrophages. Microbiology and immunology, 32(3), 275-282.

[11] Dehghani, S.; Akhlaghi, M.; and Dehghani, M. (2012). Efficacy of formalin-killed, heat-killed and lipopolysaccharide vaccines against motile aeromonads infection in rainbow trout (Oncorhynchusmykiss). Global Veterinaria., 9(4): 409-415.

[12] Lukasiewicz, J.1.; Jachymek, W.; Niedziela, T.; Kenne, L.; and Lugowski, C. (2010). Structural analysis of the lipid A isolated from Hafniaalvei 32 and PCM 1192 lipopolysaccharides. Journal of lipid research., 51(3):564-74.
[13] Jones,J.W.; Cohen,I.E.; Turecek,F.; Goodlett,D.R.; and Ernst,R.K.(2010). Comprehensive structure characterization of lipid A extracted from Yersinia pestis for determination of its phosphorylation configuration. Journal of American Society for Mass Spectrometry, 21(5):785-799.

[14] Trent, M.S.; Stead, C.M.; Tran, A.X.; and Hankins, J.V. (2006). Diversity of Endotoxin and Its Impact on pathogenesis.J.Endotox. Res., 12:205-223.

[15] Miller, S.I.; Ernst, R.K.; and Bader, M.W. (2005). LPS, TLR4, and Infectious Disease Diversity .Nat. Rev. Microbiol., 3: 36-46. Raetz, C.R.; Whitfield, C. (2002). Lipopolysaccharide Endotoxins. Annu. Rev. Biochem., 71:635-700.

[16]Dinarello, C.A. (2011). Interleukin-1 in the pathogenesis and treatment of inflammatory diseases. Blood., 117: 3720-3732.

[17] Okemoto, K.; Kawasaki, K.; Hanada, K.; Miura, M.; and Nishijima, M. (2006). A potent adjuvant monophosphoryl lipid A triggers various immune responses, but not secretion of IL-1beta or activation of caspase-1. J Immunol. , 176 (2):1203-8.

[18] Li, L.; Fei, Z.; Ren, J.; Sun, R.; Liu, Z.; Sheng, Z.; Long Wang, L.; Sun, X.; Yu, J.; Wang, Z.; and Fei, J. (2008). Functional imaging of interleukin 1 beta expression in inflammatory process using bioluminescence imaging in transgenic mice. BMC immunology., 9(1): 49.

[19] Brown, S.; and Whalen, M. (2014). Tributyltin alters secretion of interleukin 1 beta from human immune cells. Journal of Applied Toxicology.

[20] Bachmann, M. F.; and Oxenius, A. (2007). Interleukin 2: from immunostimulation to immunoregulation and back again. EMBO reports., 8(12): 1142-1148.

[21] Tawinwung, S. (2013). Role of the Adaptive Immune System in Angiotensin II Induced Vascular Remodeling and Stiffening. ( Doctoral dissertation. University of Arizona).P (23).

[22] Carozzi, S1.; Nasini, M.G.; Schelotto, C.; Caviglia, P.M.; Santoni, O.; Barocci, S.; Cantarella, S.; Versace, F.; Salit, M.; and Cantaluppi, A. ( 1989). Effect of monophosphoryl lipid A (MPLA) on peritoneal leukocyte function. AdvPerit Dial., 5:143-50.

[23] De Becker, G.; Moulin, V.; Pajak, B.; Bruck, C.; Francotte, M.; Thiriart, C.; Urbain, J.; and Moser, M. (2000). The adjuvant monophosphoryl lipid A increases the function of antigen-presenting cells. Int. Immunol., 12(6): 807-815.

[24] Balachander, A.; Nabti, S.; Sobota, R. M.; Foo, S.; Zolezzi, F.; Lee, B. T.; Poidinger, M,; and Ricciardi-Castagnoli, P. (2015). Dendritic cell derived IL-2 inhibits survival of terminally mature cells via an autocrine signaling pathway. European journal of immunology., 45(5): 1494-1499.

[25] Moore, K.W.; de Waal Malefyt, R.; Coffman, R.L.; and O'Garra, A.(2001). Interleukin-10 and the interleukin10 receptor. Annu. Rev. Immunol., 19: 683-765.

[26] Belkaid, Y.; and Chen, W. (2010). Regulatory ripples. Nature immunology., 11(12): 1077-1078.

[27]Pils x, M.C.; Pisano, F.; Fasnacht, N.; Heinrich, J.M.; Groebe, L.; Schippers, A.; Rozell, B.; Jack , R.S.; and Muller, W.(2010). Monocytes/ macrophages and / or neutrophils are the target of IL-10 in the LPS endotoxemia model. Eur.J. Immunol., 40: 443-448. 


\section{International Journal of Science and Research (IJSR) \\ ISSN (Online): 2319-7064 \\ Index Copernicus Value (2016): 79.57 | Impact Factor (2015): 6.391}

[28] de Souza, A. P.; Vale, V. L.; Silva, M. C.; Araújo, I. B.; Trindade, S. C.; Costa, L. F.; Rodrigues, G.C.; Sales, T.S.; dos Santos, H.A.; Filho, P.S.; Neto, M.G.; Schaer, R,E.; and Meyer, R. (2014). MAPK involvement in cytokine production in response to Corynebacteriumpseudotuberculosis infection. BMC microbiology., 14(1): 230.

[29] Stanic, B.; van de Veen, W.; Wirz, O. F.; Rückert, B.; Morita, H.; Söllner, S.; Tec, S.; Cezmi A. Akdis, C.A.; and Akdis, M. (2015). IL-10-overexpressing B cells regulate innate and adaptive immune responses. Journal of Allergy and Clinical Immunology., 135(3): 771-780.

[30] Salkowski, C.A.; Detore, G. R.; Vogel, S.N. (1997). Lipopolysaccharide and monophosphoryl lipid A differentially regulate interleukin-12, gamma interferon, and interleukin-10 mRNA production in murine macrophages. Infect Immun., 65(8):3239-47.

[31]Frucht, D. M.; Fukao,T.; Bogdan,C.; Schindler, H.;O Shea, J.J.; and Koyasu, S. (2001). IFN-gamma production By antigen-presenting cells:mechanisms emerge. Trends.Immunol., 22:556-560.

[32] Schloot, N. C.; Hanifi-Moghaddam, P.; Goebel, C.; Shatavi, S. V.; Flohe, S.; Kolb, H.; and Rothe, H. (2002). Serum IFN- $\gamma$ and IL-10 levels are associated with disease progression in non-obese diabetic mice. Diabetes/metabolism research and reviews., 18(1): 6470.

[33] Gao, Y. H.; Wang, J. Y.; Qiao, L. N.; Chen, S. P.; Tan, L. H.; Xu, Q. L.; and Liu, J. L. (2014). NK cells mediate the cumulative analgesic effect of electroacupuncture in a rat model of neuropathic pain. BMC complementary and alternative medicine., 14(1): 316 .

[34] Chuquimia Flores, O. D. (2011). Innate and adaptive immune responses in the lungs. Contribution to protection against mycobacterial infections. Licentiate thesis from the Department of Immunology,WennerGren Institute, Stockholm University.P(20).

[35] Arko-Mensah, J. (2008). Mycobacterial infection: Immune evasion, host susceptibility and immunological markers of diagnostic importance.(Doctoral dissertation. Stockholm University).P(29).

[36] Werner-Felmayer, G.; Baier-Bitterlich, G.; Fuchs, D.; Hausen, A.; Murr, C.; Reibnegger, G.; Werner, E.R.; and Wachter, H. (1995). Detection of bacterial pyrogens on the basis of their effects on gamma interferonmediated formation of neopterin or nitrite in cultured monocyte cell lines. Clinical and diagnostic laboratory immunology., 2(3): 307-313.

[37] Tripuwabhrut, p. (2014). Inflammatory responses of immune cells and osteoblasts in orthodonticallyinduced bone remodeling and route resorption: in vitro and in vivo studies. (Doctoral dissertation. University of Bergen). P(35).

[38] Martin, M.; Michalek, S. M.; and Katz, J. (2003). Role of Innate Immune Factors in the Adjuvant Activity of Monophosphoryl Lipid A . INFECTION AND IMMUNITy., 71(5): 2498-2507.

[39] Thalhammer, J. G.; Stöckl, W.; and Reyero, C. (1978). Effects of the B-cell activators lipid A and dextran sulphate on the antibody response to sheep red blood cells in piglets. Immunology., 35(5): 793-799.
[40] Kolb, C.; Di Pauli, R.; and Weiler, E. (1974). Induction of IgG by lipid A in the newborn mouse. The Journal of experimental medicine., 139(3): 467-478.

[41] Jennings, V. M. (1995). Review of selected adjuvants used in antibody production. ILAR Journal., 37(3):119. 125.

[42] Wunderli, P. S.; Dreesen, D. W.; Miller, T. J.; and Baer, G. M. (2003). Effects of vaccine route and dosage on protection from rabies after intracerebral challenge in mice. American journal of veterinary research., 64(4): 491-498.

[43] Yamano, T.; Higashi, T.; Nouso, K.; Nakatsukasa, H.; Kariyama, K.; Yumoto, E.; Kobayashi, Y.; Yamamoto, K.; Iwagaki,H.; Yagi,T.; Tanimoto, T.; Kurimoto,M.; Tanaka, T.; and Tsuji, T. (2000). Serum interferon-gamma-inducing factor/IL-18 levels in primary biliary cirrhosis. Clinical \& Experimental Immunology., 122(2): 227-231.

[44] Szczepanik, A. M.; Funes, S.; Petko, W.; and Ringheim, G. E. (2001). IL-4, IL-10 and IL-13 modulate A $\beta$ (1$42)$-induced cytokine and chemokine production in primary murine microglia and a human monocyte cell line. Journal of neuroimmunology., 113(1): 49-62.

[45] Roquilly, A.; Broquet, A.; Jacqueline, C.; Gautreau, L.; Segain, J. P.; de Coppet, P.; Caillon, J.; Altare, F.; Josien, R.; and Asehnoune, K. (2013). Toll-like receptor-4 agonist in post-haemorrhage pneumonia: role of dendritic and natural killer cells. European Respiratory Journal. , 42(5): 1365-1378.

Volume 6 Issue 12, December 2017 www.ijsr.net 